\title{
Wrocławskie cmentarze żydowskie - miejsca (nie)znane. Wiedza i wyobrażenia młodych mieszkańców Wrocławia'
}

\section{Abstract \\ Jewish Cemeteries in Wrocław - Places (Un)known. Knowledge and Beliefs of Young Residents of Wroctaw.}

The article is based on empirical research, one of the elements of which was to verify the knowledge, beliefs and ideas of young Wrocław residents about the Jewish cemeteries located in the city. The subject of the analysis was, first of all, knowledge of their history, importance for local culture and community; ideas about the role of cemeteries in Jewish culture and customs related to death and funeral. An important aspect was also finding out what the place of cemeteries is and how they are perceived in the local community, do they function in the minds of young people and in what way, are they really known to them and are they associated with the Jewish community living here, or rather perceived as places of memory and museum space.

Keywords: Jews, Wrocław, cemetery, sepulchral art, collective memory, memorial place

1 Termin „młodzi mieszkańcy Wrocławia” jest w artykule stosowany w znaczeniu „młodych dorosłych” lub „wczesnej dorosłości” - kategorii, którymi posługiwał się między innymi Erik Erikson (1997). Funkcjonują one także w polskiej literaturze psychologicznej do określania osób mieszczących się w przedziale wiekowym od 18-20 lat do 30-35 lat (Brzezińska, Aplet, Ziółkowska 2008). Na potrzeby artykułu przyjęto przedział wiekowy 18-35 lat, używając dla uproszczenia terminu „młodzi mieszkańcy Wrocławia”. 


\section{Wprowadzenie}

Maciej Łagiewski, autor licznych prac na temat Wrocławia i jego żydowskich cmentarzy, historyk i dyrektor Muzeum Miejskiego, zauważył: „W wielowiekowej historii każdego miasta o bogatych tradycjach niezwykle istotną rolę odegrały jego cmentarze, będące świadectwem i dokumentem dziejów oraz ludzkich żywiołów" (Łagiewski 2004: 2). Cmentarze są widomym, często jedynym znakiem czyjejś obecności, zarówno w wymiarze indywidualnym, jak i w odniesieniu do całych społeczności, czasem już nieistniejących bądź zapomnianych. Przypominają tych, którzy współtworzyli dane miejsca, kształtowali ich dzieje, ale umożliwiają również odczytywanie lokalnych historii. Przez badaczy bywają traktowane jako historyczny dokument, tekst kultury danej społeczności, ale także jako przestrzeń pamięci (Kolbuszewski 1995, 1996) czy też „przestrzenne nośniki pamięci” o przeszłości (Golka 2009: 76). Odgrywają więc istotną rolę w procesie przekazywania wiedzy na temat lokalnych społeczności i ich kultury, a także są miejscami pamięci o nich.

Cmentarze jako przedmiot badań cieszyły się zainteresowaniem badaczy bardzo różnych specjalności. Z perspektywy antropologii pamięci kwestię tę podejmowali między innymi Sławomir Sikora (1986) i Grażyna Ewa Karpińska (2017), z punktu widzenia semiotyki cmentarze jako specyficzny tekst kultury badał Jacek Kolbuszewski $(1995,1996)$, zagadnieniem ich miejsca w turystyce kulturowej zajmował się natomiast Sławoj Tanaś (2008a, 2008b). O cmentarzach zapomnianych, niepamiętanych i przywracanych pamięci w ostatnich latach pisały między innymi Małgorzata Fabiszak i Anna Weronika Brzezińska (2018), a także Małgorzata Zawiła (2019a, 2019b), rozpatrująca zagadnienie przedwojennych cmentarzy na terenach postimigracyjnych Polski w kontekście pojęcia dziedziczynienia ${ }^{2}$.

Liczne grono badaczy reprezentujących różne dziedziny nauki podejmowało również bezpośrednio tematykę cmentarzy żydowskich, analizując nie tylko ich specyfikę kulturową, symbolikę nagrobków czy inskrypcje, ale także stan ich zachowania, lokalizację, sposoby ochrony czy sytuację prawną (między innymi Bednarek 2020; Bielawski 2020; Gadowska 2017a, 2017b; Grzywa 2010; Hońdo 2002; Jagielski 1995; Krajewska 1986; Majewska 2016a, 2016b; Rozmus 2015; Steuer-Jurek 2019; Trzciński 1997, 2010; Walerjański 1998; Woronczak 1991, 1995) oraz odnosząc się do zwyczajów związanych ze śmiercią i pogrzebem w kulturze żydowskiej (między innymi Banasiewicz-Ossowska 2005, 2014; Goldberg-Mulkiewicz 1986, 2000; Skrok 1991; Wilczura 2010). Ciekawą inicjatywą jest również wydany niedawno podręcznik dobrych praktyk, mający stanowić wsparcie dla działaczy i społeczników zajmujących się ochroną oraz inwentaryzacją

2 Odpowiednik terminu heritagisation/heritagisation - „czynienie/tworzenie dziedzictwa”, „Czynienie/tworzenie dziedzictwem” (zob. Zawiła 2019b: 86). 
dziedzictwa lokalnego, jakim są żydowskie cmentarze (Klimowicz i in. 2018). Problematyka cmentarzy żydowskich z Europy Środkowej i Wschodniej, w kontekście dziedzictwa kulturowego regionu, jego znaczenia i ochrony, ale także konsekwencji masowej turystyki, pojawiała się także w pracach zagranicznych (Carmel, Gruber, Szemző, Tönkő, Vonnák 2020; Klein 2015, 2019; Reisenthel 2015). Wreszcie wiele opracowań poświęcono wrocławskim cmentarzom żydowskim, które stały się przedmiotem zainteresowania polskich judaistów, historyków czy archeologów (między innymi Goliński, Ziątkowski 1989; Kichler 2015; Łagiewski 1991, 2004; Okólska, Burak 2007; Stawiarski 2010; Wodziński 1992, 1994).

\section{Problematyka badań}

Celem artykułu jest przedstawienie wstępnych wniosków z szerszych badań empirycznych, których jednym z elementów była weryfikacja wiedzy, a także przekonań i wyobrażeń młodych mieszkańców Wrocławia na temat cmentarzy żydowskich znajdujących sięna terenie miasta. Badania prowadzono na przełomie czerwca ilipca 2019 roku metodą wywiadów pogłębionych, ustrukturyzowanych kwestionariuszem, w ramach których odbywano rozmowy z osobami pełnoletnimi, we wszystkich kategoriach wiekowych; dotyczyły one szerszego kontekstu, jakim były wiedza o Żydach wrocławskich i miejscach z nimi związanych oraz ich postrzeganie ${ }^{3}$. Na potrzeby artykułu dokonano analizy 56 wywiadów z młodymi mieszkańcami miasta, między 18. a 35. rokiem życia. Były to osoby urodzone i mieszkające we Wrocławiu (UW), a także urodzone poza Wrocławiem, ale zamieszkujące w mieście przynajmniej od pięciu lat $(\mathrm{SW})^{4}$. Szczegółowej analizie poddano wypowiedzi 42 osób, które podczas badań zadeklarowały, że odwiedziły choćby jeden z cmentarzy wrocławskich albo przynajmniej były świadome ich istnienia, a jednocześnie miały pewną wiedzę lub wyobrażenia na temat specyfiki żydowskich cmentarzy i praktykowanych na nich zwyczajów. Pozostałe 14 osób nie wiedziało o ich istnieniu w mieście, nigdy nie było na żadnym cmentarzu żydowskim ani nie miało wiedzy na temat praktykowanych tam zwyczajów ( 8 z grupy UW i 6 z grupy SW). Badania prowadzono głównie $w$ miejscach kojarzonych ze społecznością żydowską: w okolicach Synagogi pod Białym Bocianem, ulicy Włodkowica, ulicy św. Antoniego, na promenadzie położonej w pobliżu Fosy Miejskiej, a także

3 Częściowe wyniki badań opublikowano w artykule: Żydzi wrocławscy w świadomości młodych mieszkańców Wrocławia - wiedza i stereotypy (Banasiewicz-Ossowska 2020).

4 Rozmówcami podczas badań były 33 kobiety i 23 mężczyzn, w tym 19 osób z wykształceniem wyższym, 34 średnim, spośród których 26 było w trakcie studiów wyższych, 3 osoby nie udzieliły odpowiedzi na pytanie o wykształcenie; 24 osoby (43\%) urodziły się we Wrocławiu, a 32 (57\%) pochodziły z innych miejscowości. Osoby mieszkające w mieście od urodzenia oznaczono w artykule skrótem UW, a osoby przyjezdne SW. Badania prowadzono wraz ze studentami etnologii i antropologii kulturowej Uniwersytetu Wrocławskiego. 
w okolicy starego cmentarza żydowskiego znajdującego się przy ulicy Ślężnej i nowego cmentarza żydowskiego przy ulicy Lotniczej. Respondentami były wówczas napotkane, przypadkowe osoby. Wywiady przeprowadzano również z osobami zwiedzającymi cmentarze, tuż po zakończeniu oglądania i poza ich terenem. Pytania uwzględniały każdorazowo szerszy kontekst cmentarzy żydowskich we Wrocławiu, nie tylko tego jednego, aktualnie zwiedzanego. Odbywano również rozmowy z osobami poleconymi przez respondentów i wcześniej umówionymi. Miały one miejsce w różnych lokalizacjach, najczęściej w kawiarniach i parkach.

Przedmiotem analizy były: wiedza dotycząca historii i znaczenia nekropolii dla lokalnej kultury i społeczności, postrzeganie cmentarzy, ich przestrzeni i form nagrobków, a także wiedza i wyobrażenia na temat praktykowanych przez Żydów zwyczajów związanych ze śmiercią i pogrzebem oraz na temat znaczenia cmentarzy w kulturze żydowskiej. Respondentów pytano także o to, czy zwiedzali cmentarze żydowskie we Wrocławiu lub w innych miejscach, jakie motywacje nimi kierowały, gdy wybierali je jako cel odwiedzin oraz jakie są źródła posiadanej przez nich wiedzy. Bardzo ważnym aspektem było określenie, jakie jest miejsce cmentarzy żydowskich i ich odbiór w lokalnej społeczności, czy obiekty te funkcjonują w świadomości i pamięci młodych ludzi, a jeśli tak, to w jaki sposób, czy są traktowane wyłącznie jako punkty orientacyjne na mapie miasta, czy też jako cenne i warte poznania dziedzictwo historyczne i kulturowe, stanowiące o jego specyfice. Czy wobec deklaracji większości rozmówców o tym, iż „słyszeli” o żydowskich cmentarzach, „wiedzą” o ich istnieniu, „znają" je, rzeczywiście są to miejsca znane młodym mieszkańcom miasta i czy są kojarzone z żyjącą we Wrocławiu społecznością żydowską.

Warto w tym miejscu zaznaczyć, że - jak dotąd - nie podjęto podobnej próby analizy wiedzy na temat dziedzictwa żydowskiego, jakim są cmentarze żydowskie, sposobu ich postrzegania i funkcjonowania w świadomości młodych ludzi, którzy w większości nie mają dziś kontaktu ze społecznością żydowską ani możliwości obcowania z kulturą żydowską.

Wrocław, będący terenem prowadzonych badań, jest miejscem szczególnym, ponieważ w odróżnieniu od wielu polskich miast i miasteczek, w których możemy odnaleźć cmentarze żydowskie, wciąż zamieszkuje go społeczność żydowska. Nie stanowi ona jednak bezpośrednich spadkobierców dziedzictwa pozostawionego przez Żydów z Breslau. Podobnie jak pozostali mieszkańcy miasta, współcześni Żydzi wrocławscy reprezentują ludność napływową, oni również musieli poznać, nauczyć się i zaakceptować opuszczone dziedzictwo i uczynić je częścią swojej pamięci kulturowej (zob. Gogol, Henke, Hoffman, Kazejak, Sęczek 2005). Podejmując wiele działań mających na celu edukację międzykulturową i międzyreligijną, społeczność ta stara się upowszechniać wśród mieszkańców wiedzę na temat Żydów w przedwojennym i współczesnym Wrocławiu oraz podtrzymywać pamięć o dawnych mieszkańcach i pozostawionym dziedzictwie. Organizowane przez nią lub z jej udziałem wydarzenia, takie jak zwiedzanie miasta wraz z prze- 
wodnikiem śladami Żydów wrocławskich, Festiwal Kultury Żydowskiej SIMCHA, różnego rodzaju wykłady, warsztaty czy wystawy na temat historii niemieckich i polskich Żydów, jak wynika z obserwacji, przyciągają zwłaszcza młodych ludzi. W zachowanie i promowanie żydowskiego dziedzictwa angażuje się także miasto współpracujące w tej sferze ze społecznością żydowską, wspierające między innymi odbudowę Synagogi pod Białym Bocianem, a także wydawanie publikacji odkrywających żydowskie ślady w przestrzeni miejskiej (Kichler, Włodarczyk 2016). Wrocław jest też jednym $z$ niewielu miast w Polsce, w którym można zobaczyć Stolpersteine - kamienie pamięci wmurowywane w chodnik, upamiętniające przedwojennych żydowskich mieszkańców miasta ${ }^{5}$. Podejmuje się wiele działań, również badawczo-naukowych, które wpisują się w szersze zjawisko „archeologii żydowskiej” opisywane przez Ruth Gruber (2004: 93). Wydaje się więc, że Wroclaw jest miejscem, w którym istnieją sprzyjające warunki, by poznawać żydowską kulturę w jej współczesnych przejawach (możliwość uczestniczenia w świętach w gminie), ale także żydowską przeszłość miasta i jego topografię, w tym również żydowskie cmentarze.

Kategorią przydatną z punktu widzenia analizowanego problemu jest pamięć zbiorowa, którą będę się posługiwać zgodnie z definicją zaproponowaną przez Barbarę Szacką, rozumiejąc ją jako wyobrażenia o przeszłości własnej grupy, konstruowane przez jednostki z zapamiętanych informacji, które pochodzą z różnych źródeł, docierają różnymi kanałami i które są rozumiane, selekcjonowane i przekształcane według własnych standardów kulturowych oraz przekonań światopoglądowych. Ponieważ są wytwarzane społecznie, stają się wspólne członkom zbiorowości, co skutkuje ujednoliceniem ich wyobrażenia o przeszłości (Szacka 2006: 44, por. Gliwka 2019: 16). Podobne rozumienie pojęcia znajdujemy także u Mariana Golki, posługującego się w tym kontekście kategorią pamięci społecznej, którą definiuje jako „społecznie tworzoną, przekształcaną, względnie ujednolicaną i przyjmowaną wiedzę, odnoszącą się do przeszłości danej zbiorowości. Wiedza ta obejmuje różne treści, pełni różne funkcje, trwa dzięki różnym kulturowym nośnikom oraz trafia do świadomości jednostek z różnych źródeł" (Golka 2009: 15). Pamięć zbiorowa i ramy społeczne wyznaczone przez wspólnotę modyfikują zatem pamięć jednostkową.

W artykule założono, że analizowana wiedza, przekonania i wyobrażenia grupy badanych na temat wrocławskich cmentarzy żydowskich, a więc części pozostawionego dziedzictwa żydowskiego, mają związek z charakterem pamięci zbiorowej mieszkańców miasta, społeczności przymusowo przesiedlonej wskutek powojennych migracji na tereny zachodnie bądź osiedlającej się tu w latach późniejszych, nieodczuwającej więzi międzypokoleniowej, kulturowej czy społecznej

${ }^{5}$ O niechęci wielu polskich miast do takiego sposobu upamiętniania żydowskich mieszkańców dyskutowano podczas specjalnej debaty: Stolpersteine w Polsce - kto, kogo i dla kogo upamiętnia?, OP ENHEIM i Fundacja Współpracy Polsko-Niemieckiej, 14 listopada 2020, https://www.facebook. com/openheim/videos/306634487013342 (dostęp: 14.11.2020). 
z dawnymi mieszkańcami. Co także istotne, badana grupa to osoby młode, które nie miały kontaktów z Żydami i ich kulturą w takiej formie, w jakiej funkcjonowała do czasów zagłady, nie mają też własnych wspomnień i doświadczeń na ten temat, ani kontaktów z Żydami żyjącymi współcześnie we Wrocławiu'; niewiele osób uczestniczyło także w wydarzeniach, które dotyczyły Żydów lub kultury żydowskiej.

\section{Wrocławskie cmentarze żydowskie - rys historyczny}

Historia cmentarzy żydowskich we Wrocławiu sięga średniowiecza, a w obecnych granicach miasta istniało ich w różnym czasie aż sześć. Najstarszy z udokumentowanych ${ }^{7}$ powstał pod koniec XII wieku i znajdował się poza murami miejskimi, w pobliżu dawnej Bramy Oławskiej, w rejonach dzisiejszych ulic Podwale, Traugutta i Krasińskiego. Jego likwidacja zaczęła się już w 1345 roku na mocy decyzji króla czeskiego, Jana Luksemburskiego, a pochodzące z niego macewy wykorzystano jako materiał budowlany - znaleziono je później między innymi w Ratuszu Miejskim i Katedrze św. Jana Chrzciciela. Według niektórych badaczy to z tego cmentarza miałaby pochodzić najstarsza zachowana macewa na ziemiach polskich, datowana na 1203 rok, należąca według inskrypcji do kantora Dawida, syna Sar Szaloma ${ }^{8}$. Kolejny cmentarz, otwarty w 1761 roku, był zlokalizowany na Przedmieściu Świdnickim, pomiędzy dzisiejszymi ulicami Piłsudskiego, Gwarną i Placem Konstytucji; pełnił on funkcje grzebalne do 1856 roku. Kilkadziesiąt nagrobków zachowało się jeszcze do okresu powojennego, ale ostatecznie zostały w większości wywiezione, a teren cmentarza zniwelowano dopiero w latach 60 . lub 70. XX wieku. Obecnie jest on zabudowany (Kichler, Włodarczyk 2016: 126). W 1856 roku udostępniono społeczności wrocławskich Żydów nowy cmentarz, umiejscowiony przy dzisiejszej ulicy Ślężnej 37/39, na którym ostatni pochówek odbył się w 1942 roku. Cmentarz ten, nazywany dziś starym, jest jednym $\mathrm{z}$ dwóch istniejących w mieście i stanowi część Muzeum Miejskiego jako Muzeum Sztuki Cmentarnej. Jedynym cmentarzem użytkowanym przez społeczność żydowską i należącym do Gminy Wyznaniowej Żydowskiej we Wrocławiu jest obecnie kirkut przy ulicy Lotniczej 51, otwarty w 1902 roku, będący założeniem przestrzenno-parkowym. Na terenie obecnego Wrocławia miały istnieć jeszcze dwa cmentarze, jeden $\mathrm{z}$ nich, założony w XIX wieku, był zlokalizowany w dzi-

6 Sześć osób zadeklarowało, że zna lub znało osobę pochodzenia żydowskiego, ale znajomość ta nie wiązała się z bliskimi kontaktami.

7 Mateusz Goliński i Leszek Ziątkowski (1989) sugerowali istnienie jeszcze jednego, starszego cmentarza na terenie miasta. Teza ta nie została jednak potwierdzona, a $z$ wnioskami badaczy polemizował Marcin Wodziński (1994).

8 Obecnie macewa znajduje się w Muzeum Miejskim Wrocławia w Pałacu Królewskim. 
siejszej dzielnicy Psie Pole, przy ulicy Sycowskiej, i funkcjonował do 1945 roku. Współcześnie nie ma po nim śladu. Drugi miał się znajdować w dzielnicy Leśnica (Kichler 2015: 42; Kichler, Włodarczyk 2016: 150-151).

Pamięć o tych historycznych, nieistniejących już nekropoliach żydowskich, w których miejscu znajdują się zabudowania, place i ulice, nie przetrwała w świadomości młodych mieszkańców miasta (por. Okólska, Burak 2007; Fabiszak, Brzezińska 2018). Podczas badań nie wspomniał o nich żaden z rozmówców. Tylko jedna z osób wiedziała o wzmiankowanej już najstarszej w Polsce macewie, znajdującej się we Wrocławiu, należącej do Dawida, syna Sar Szaloma, którego nazwała „pierwszym Żydem we Wrocławiu i kupcem” (W9) 9

\section{Wrocławskie cmentarze żydowskie - wiedza, przekonania i wyobrażenia badanych}

\section{Stary cmentarz żydowski}

Stary cmentarz żydowski, nazwany przez Łagiewskiego „w całości naturalnym pomnikiem narodu skazanego podczas II wojny światowej na zagładę" (Łagiewski 2004: 2), był najczęściej przywoływanym - zaraz po Synagodze pod Białym Bocianem - ale także często odwiedzanym, zgodnie z wypowiedziami respondentów, miejscem identyfikowanym z Żydami. Część respondentów nie potrafiła jednak wskazać jego poprawnej lokalizacji, umiejscawiając go między innymi na ulicy Powstańców Śląskich, Borowskiej czy Oporowskiej. O jego istnieniu wiedziały 42 osoby ( 18 z grupy UW i 24 z grupy SW), które określały go najczęściej jako miejsce upamiętniające przedwojennych przedstawicieli tej społeczności. Według deklaracji zwiedziły go wraz z przewodnikiem lub samodzielnie 23 osoby (11 z grupy UW i 12 z grupy SW), niektóre kilkukrotnie. Pozostałe z tych osób twierdziły, że słyszały o istnieniu cmentarza, ale nigdy na nim nie były, ponieważ - jak mówiły nie były nim zainteresowane, nie interesują się też historią ani Żydami; niektórzy z respondentów byli przekonani, że mogą go zwiedzać wyłącznie zorganizowane wycieczki i zapowiedziane wcześniej grupy, a nie osoby indywidualne.

Mimo że dość duża grupa rozmówców zwiedzała cmentarz, z reguły nie znali oni jego historii, nie wiedzieli, kiedy powstał, kiedy zaprzestano na nim pochówków oraz jakie były jego wojenne i powojenne losy. Niektórzy domyślali się, że jest „jeszcze przedwojenny”, ponieważ są na nim nagrobki sprzed pierwszej wojny światowej, inni, że został zamknięty prawdopodobnie po drugiej wojnie światowej. Jedna $\mathrm{z}$ osób, która zwróciła uwagę na ślady po kulach widoczne na nagrobkach, skojarzyła je z walkami trwającymi na terenie cmentarza. Zaznaczyła

\footnotetext{
9 W nawiasach podano numery wywiadów.
} 
również, że Żydzi zbudowali dla siebie tak duże grobowce po to, by schronić się w nich w czasie wojny, gdyż - jak sądziła - byli przekonani, że Niemcy nie odważą się wejść na cmentarz żydowski (W16). W wypowiedzi tej można wyraźnie dostrzec echa dawnego prawa azylu, na mocy którego cmentarz stawał się miejscem schronienia dla ściganych, a jego naruszenie traktowano jako świętokradztwo (Kolbuszewski 1996: 39, 64-65).

Rozmówcy, opowiadając o starym cmentarzu żydowskim, zwracali uwagę przede wszystkim na jego walory estetyczne. Dostrzegali zróżnicowanie form nagrobków, wymieniając macewy, grobowce i kolumny. Jedna z osób, która oceniła cmentarz jako miejsce pochówku bogatszych Żydów, zwróciła również uwagę na rozplanowanie kwater: „zewnętrzna część to są bardzo okazałe, ogromne grobowce, (...) naprawdę śliczne, a w środku z kolei są tylko macewy stojące” (W3). Zauważono także wydzielenie części, na których znajdują się starsze i nowsze nagrobki. Cmentarz uznawano za przykład znakomitej sztuki sepulkralnej i wybitnej małej architektury. Grobowce porównywano z małymi świątyniami, wykonanymi z cennych materiałów, takich jak marmur. Tym, co według rozmówców odróżniało ten cmentarz od chrześcijańskich miejsc pochówków, była odmienna symbolika na nagrobkach, na przykład gwiazdy Dawida zamiast krzyży, duże zadrzewienie oraz szerokie alejki (W7), pozostawianie kamieni zamiast kwiatów, a także fakt, że „na wielu grobach stały tylko proste tablice” (W8). Część osób podkreślała dużą wartość historyczną nekropolii, zauważając, że jest ona miejscem pochówku wielu wybitnych mieszkańców Wrocławia: profesorów, lekarzy czy naukowców (W5). Nie potrafiono jednak sprecyzować tej informacji albo podawano informacje błędne, jak na przykład tę o pochowaniu na cmentarzu Edyty Stein (W3), choć w rzeczywistości znajdują się tu groby jej rodziców.

Bardzo duże wrażenie na zwiedzających wywierała przestrzeń cmentarza, znajdująca się tu bujna roślinność, stary drzewostan, krzewiący się bluszcz i kwitnące wiosną kwiaty. W wielu wypowiedziach podkreślano jej niezwykłość oraz panujący tam specyficzny klimat, ciszę i spokój, sprzyjające zadumie. Cmentarz opisywano najczęściej jako: piękny, pełen zieleni, ale też magiczny, tajemniczy, ukryty za wysokim murem, którego przekroczenie sprawiało wrażenie wejścia $\mathrm{w}$ inny świat. Jeden z respondentów zauważył, że „tam jak człowiek wejdzie, to zwyczajnie czuje się jak w innym świecie, bo ta architektura się wyróżnia i po prostu (...) doznaje człowiek estetycznych uniesień, dziwnie to brzmi, ale jest tam po prostu ładnie” (W1). Inna z osób porównała go z „ogrodem pamięci”, w którym nic nie można zmieniać ze względu na zasadę nienaruszalności grobów i miejsca. Z powodu jego architektury i specyficznego klimatu kojarzył się jej z filmem Opowieści z Narnii (W7). Z kolei kobieta, która określiła się jako „fascynatka cmentarzy”, oceniła, że to „niesamowite (...) że taki mur oddziela dwa światy i za kilka złotych można wejść w inny, historyczny świat. A mało ludzi o tym wie i (...) odwiedza ten cmentarz" (W9). Podkreślano, że dziś cmentarz jest bardzo zadbany, ale dostrzegano także problemy dewastacji czy kradzieży, jakich doświadczał 
w przeszłości. Został uznany za bardzo interesujące miejsce, które warto zobaczyć i poznać, przeznaczając na to nawet kilka godzin. Co było ważne z perspektywy rozmówców, można zwiedzać go w każdą niedzielę z przewodnikiem z Muzeum Miejskiego. Według jednej z osób, warto odwiedzić go właśnie tego dnia, ponieważ wówczas można także spotkać odwiedzających groby Żydów przyjeżdżających z zagranicy (W7). Regularne oprowadzanie z przewodnikiem odbywa się już od wielu lat i jest znaną inicjatywą dzięki zajęciom edukacyjnym dla dzieci i młodzieży prowadzonym przez Muzeum, ale także dzięki postom zamieszczanym na Facebooku, trafiającym do młodych odbiorców. Działania podejmowane przez Muzeum Miejskie mają więc wpływ na to, jakie jest miejsce i odbiór starego cmentarza w lokalnej społeczności.

\section{Nowy cmentarz żydowski}

Niewiele osób odwiedziło nowy cmentarz żydowski przy ulicy Lotniczej - było to tylko 8 respondentów ( 4 z grupy UW i 4 z grupy SW). Większa grupa, bo 21 osób ( 9 z grupy UW i 12 z grupy SW), miała świadomość jego istnienia i wymieniała go jako jedno z miejsc, które ma służyć upamiętnieniu społeczności żydowskiej Wrocławia. Jak można wywnioskować z wypowiedzi respondentów, tak duża dysproporcja pomiędzy liczbą osób, które odwiedzały stary i nowy cmentarz, może wynikać z faktu nieudostępniania tego drugiego przez dłuższy czas dla zainteresowanych, nawet w przewidzianych godzinach otwarcia, co podkreślali rozmówcy. Utarło się więc przekonanie, że cmentarza przy ulicy Lotniczej nie można zwiedzać, nie można wejść na jego teren i że jest to możliwe jedynie za specjalnym zezwoleniem albo nielegalnie (W7). Nowy cmentarz jawił się więc większości rozmówców jako miejsce niedostępne, nieosiągalne. Od niedawna na jego terenie - podobnie jak na cmentarzu przy ulicy Ślężnej - organizuje się zwiedzania grupowe z przewodnikiem, ale odbywają się one nieregularnie. Można dowiedzieć się o nim, śledząc posty zamieszczane na Facebooku wrocławskiej gminy żydowskiej, o której istnieniu we Wrocławiu wie jednak niewiele młodych osób (Banasiewicz-Ossowska 2020: 174). Jedna z respondentek, która skorzystała z takiej możliwości, przyznała, że na to wydarzenie czekała aż sześć lat, od kiedy przyjechała do Wrocławia na studia: „był to ostatni cmentarz na mojej liście wrocławskiej” (W9). Cmentarz budzi więc ciekawość i przyciąga zainteresowanych swoją niedostępnością, ale też historią oraz specyficznym klimatem tajemniczości, wynikającym z tego, że część jego terenu jest nadal wyłączona ze zwiedzania, zarośnięta drzewami i gęstą roślinnością. Rozmówczyni spotkana podczas jego zwiedzania, zapytana o wrażenia i opinię na temat specyfiki cmentarza, zwróciła uwagę przede wszystkim na liczne pionowe macewy, brak zdjęć osób zmarłych na nagrobkach oraz napisy w językach hebrajskim i niemieckim, znajdujące się „nie po tej stro- 
nie, co u nas”. Odniosła też wrażenie „ogólnego zaniedbania” (W33). Podobną opinię wyraziła osoba, która była na cmentarzu kilka lat wcześniej z rodzicami i również zapamiętała go jako bardzo zaniedbany, a przy tym „trochę się bała”, bo „wyglądało, jakby to wszystko tam miało się zaraz zapaść pod ziemię” (W19).

Teren cmentarza przez wiele lat był rzeczywiście w bardzo złym stanie, co znajduje odzwierciedlenie w wypowiedziach informatorów. Dopiero w 1996 roku obiekt został przejęty od Zarządu Zieleni Miejskiej przez Gminę Wyznaniową Żydowską we Wrocławiu - rozpoczęto wówczas stopniowe, rozłożone na lata, prace porządkowe, zabezpieczające i renowacyjne, powodujące czasowe zamknięcie nekropolii dla zwiedzających, choć nadal odbywały się na niej pochówki Żydów wrocławskich i dolnośląskich. Postrzeganie cmentarza jako terenu zaniedbanego i zamkniętego jest więc z jednej strony spowodowane rzeczywistym wieloletnim brakiem odpowiedniej opieki, $\mathrm{z}$ drugiej zaś także nieznanymi większości respondentów przepisami religijnymi, zabraniającymi usuwania $\mathrm{z}$ cmentarzy roślinności, ingerowania w ich przestrzeń, aby nie naruszyć grobów, które mają przetrwać w stanie niezmienionym do dnia Sądu Ostatecznego. To, że cmentarz stanowi własność gminy żydowskiej i jest nadal czynnym miejscem pochówków, również powoduje, że ma on inny charakter, podlega przepisom żydowskiego prawa religijnego, co może wpływać na odmienne zasady jego udostępnienia.

Warto odnotować, że nikt z rozmówców, nawet osoby, które zwiedzały cmentarz, nie wspomniał o istnieniu na jego terenie budynku dawnego domu przedpogrzebowego, choć jest on dobrze widoczny także z zewnątrz, ponieważ znajduje się blisko ogrodzenia, w zachodniej części cmentarza, po lewej stronie od wejścia. Respondenci nie zdawali sobie także sprawy ze znaczenia przestrzeni cmentarza, tradycyjnego układu kwater, oddzielnie lokalizowanych dla kobiet, mężczyzn i dzieci. Można także odnieść wrażenie, że cmentarz funkcjonuje w świadomości rozmówców jakby w oderwaniu od żyjącej w mieście społeczności żydowskiej, jako pozostałe po Żydach miejsce grzebalne. Nikt z rozmówców nie wspomniał, iż należy on do gminy żydowskiej i nadal jest użytkowany przez społeczność żydowską, nie zwrócił uwagi na fakt pojawiania się nowych grobów, organizowania pogrzebów. Obserwacja ta potwierdza spostrzeżenia badaczki cmentarzy żydowskich, Alicji Mroczkowskiej (2016: 128), która pisała „W świadomości lokalnej mają status niczyich. Nawet jeśli należą do miasta, skarbu państwa bądź do gmin żydowskich, to ta informacja nie jest dokładnie nikomu znana”.

Z wypowiedzi rozmówców wynika, że zdecydowana większość z nich, podejmując decyzję o zwiedzeniu obu lub jednego ze wspomnianych cmentarzy, kierowała się ciekawością, chęcią zetknięcia się z inną kulturą, a jednocześnie poznania jakiegoś nowego, niezwykłego miejsca mającego wartości historyczne, dowiedzenia się czegoś więcej o mieście, w którym się urodzili lub zamieszkali. Motywy te zdają się potwierdzać obserwacje Tanasia, który pisał, iż „cmentarze mają istotne znaczenie $\mathrm{w}$ zaspokajaniu przez odwiedzających (...) potrzeb poznawczych związanych z poznawaniem kultury własnej lub innej społeczności” (Tanaś 2008a: 5). Cmen- 
tarze żydowskie, będąc przestrzenią spotkania $\mathrm{z}$ inną kulturą, pełnią więc ważną funkcję edukacyjną, a jako ciekawe miejsca historyczne stały się też częścią przestrzeni turystycznej (zob. Tanaś 2008a: 11, 14-15). Obok motywów poznania i ciekawości w wielu wypowiedziach można także dostrzec rekreacyjny cel ich odwiedzania: dla urokliwych spacerów, wypoczynku w otoczeniu pięknej przyrody i architektury, które można udokumentować na fotografiach. Dla wielu z odwiedzających są to oazy spokoju, położone w ruchliwych częściach miasta, w których można odnaleźć ciszę i pozwolić sobie na chwilę zadumy. Na takie szczególne walory cmentarzy żydowskich zwracał uwagę już na początku XX wieku Majer Bałaban, pisząc, że: „są nieraz cmentarze żydowskie bardzo romantycznie położone i przy dobrej konserwacji mogłyby służyć za miejsce przechadzki dla ludności żydowskiej, pozbawionej często jakiegokolwiek ogrodu" (Bałaban 1929: 117).

Cmentarze żydowskie, w języku hebrajskim nazywane be(j)t chajim - dom życia [wiecznego], be(j)t kwarot - dom grobów lub be(j)t olam - dom świata [wiecznego], od dawna budziły zainteresowanie ludności polskiej, przez którą były określane najczęściej jako kirkut, kierkow (od niem. der Kirchhof - dziedziniec kościelny) czy okopisko (od czynności „okopywania”, czyli ogradzania) (Borzymińska, Żebrowski 2003: 296-297). Choć postrzegano je jako miejsca tajemnicze i potencjalnie niebezpieczne, na których odbywają się niezrozumiałe i podejrzane rytuały, budziły też zaciekawienie, czasem podglądano więc, co się na nich dzieje (Banasiewicz-Ossowska 2007: 131). Wiązały się też z nimi, a także z żydowskimi zwłokami, makabryczne przesądy, mówiące na przykład o zakopywaniu żydowskiego trupa pod progiem obory owczarza, któremu chciano wybić stado (Biegeleisen 1930: 85), o wykorzystywaniu włosów nieboszczyka do przygotowania napoju mającego zadać kołtuna lub o okadzaniu chorego na tyfus dymem z kości Żyda wykopanych na cmentarzu (Biegeleisen 1929: 67-68). Współcześnie żadna $\mathrm{z}$ młodych osób uczestniczących w badaniach nie odwoływała się do tego typu przesądów i wierzeń, ale - co ciekawe - nie użyła również w swoich wypowiedziach terminów kirkut czy okopisko, co może sugerować ich nieznajomość wśród młodego pokolenia (w wywiadach ze starszymi ludźmi terminy te występowały). Zaledwie kilka osób użyło też świadomie nazwy macewa, mówiąc o tradycyjnych nagrobkach. Warto jednak podkreślić, że część z rozmówców była świadoma różnic kulturowych i odmienności zwyczajów kultury żydowskiej, które wpływają na charakter żydowskiego cmentarza i praktykowanych tu rytuałów. Jedna z informatorek, która odniosła się do zwyczaju sporadycznego odwiedzania grobów osób bliskich przez Żydów, zauważyła, że „Żydzi nie dbają tak jak chrześcijanie o groby", nie przyjeżdżają na nie co roku, nie sprzątają ich i nie przynoszą kwiatów, ale wyjaśniła jednocześnie, że na cmentarz żydowski „nie powinno się przynosić żywych rzeczy" i nie należy ingerować w groby, które muszą pozostać w stanie nienaruszonym. „Natura przejmuje je we władanie”, ponieważ nie wolno także ścinać drzew, chyba że zagrażają bezpieczeństwu, „to jest takie połączenie człowieka z naturą" (W7, W16). Osoby nieznające żydowskich zwyczajów i prze- 
pisów religijnych przenosiły na kulturę żydowską własne wzorce kulturowe, wyrażając zdecydowaną dezaprobatę dla tych, którzy zaniedbują swoje groby. W tradycji żydowskiej nie ma jednak święta poświęconego zmarłym, a na cmentarze - ze względu na nieczystość rytualną ich przestrzeni, a także samych zmarłych - przychodzi się podczas pogrzebów, w rocznicę śmierci bliskich oraz po to, by odwiedzić grób słynnego rabina (Woronczak 1991: 7). Na obu cmentarzach zaobserwowano zwyczaj zostawiania kamieni na grobach, ale nie potrafiono wyjaśnić jego genezy. Sugerowano, że być może chodzi o ich wieczność czy trwałość w kontekście zachowywanej pamięci o zmarłym. W nawiązaniu do tego zwyczaju pojawiły się także negatywne komentarze będące z jednej strony wynikiem jego niezrozumienia, a z drugiej skutkiem ujawnianej przez rozmówców niechęci do Żydów i posługiwania się stereotypami, zasugerowano bowiem, że Żydzi pozostawiają kamienie, bo „nawet na zniczach oszczędzają? (W6), i że są sprytni, „bo nikt im tego nie ukradnie" (W3). Kilka osób zwróciło uwagę na to, że mężczyźni, tak jak w synagogach, również na cmentarzach powinni nosić nakrycia głowy (W33), a na pogrzeby należy się ubierać na biało, nie na czarno (W35). Dostrzegano także odmienną symbolikę występującą na żydowskich nagrobkach, nie potrafiono jej jednak opisać.

Pojawiły się również pojedyncze, ale ciekawe, nieco bardziej szczegółowe wypowiedzi na temat zwyczajów pogrzebowych i rytuałów związanych ze śmiercią. Jedna z informatorek zauważyła, że pogrzeb żydowski wygląda inaczej niż w polskiej kulturze, że czuwa się przy zwłokach, a Żydzi odmiennie postrzegają ciało po śmierci, ponieważ wierzą, iż posiadają kilka dusz: „Oni w ogóle wierzą w kilka dusz i jedna zawsze zostaje tutaj na ziemi, dlatego też w ogóle nie powinno się ingerować w cmentarz, no bo te dusze tam są, żeby zostały". Miała również świadomość istnienia rytuału tahara, choć nie posłużyła się jego nazwą, wiedziała, że polega na obmyciu zwłok i jak stwierdziła: „dużo więcej się tam robi [przy zmarłym - EBO] niż w chrześcijaństwie". Podkreśliła także, że zwłoki w grobie są układane na leżąco oraz zakazane są ich sekcja, kremacja i ekshumacja, choć współcześnie odstępuje się od niektórych zakazów, przy czym to - według jej wiedzy - nie jest dobrze widziane przez większość społeczności żydowskich (W16). Także dwie inne osoby wspominały o istnieniu „specjalnych rytuałów pośmiertnych”, których nie potrafiły jednak bliżej opisać, a jedna stwierdziła, że przy kolejnym pochówku przeprowadzanym w tym samym grobie nie można naruszyć poprzedniego (W7).

W przypadku takich rozmówców, dysponujących bardziej szczegółową wiedzą na badany temat, można mówić o samodzielnym i świadomym jej poszukiwaniu, które wynikało z zainteresowania kulturą żydowską i cmentarzami w ogóle, a także z wykształcenia i związanego z nim doświadczenia (na przykład historyk, studentka urbanistyki). Jak wspomniano, część osób uczestniczyła w zwiedzaniu wrocławskich cmentarzy z przewodnikiem, podczas których przekazuje się wiedzę na temat historii Żydów wrocławskich oraz zwyczajów pogrzebowych. Niektórzy odwiedzali nekropolie żydowskie także w innych regionach kraju, na 
przykład w Krakowie, w Białymstoku czy na Górnym Śląsku. Brali również udział w różnego rodzaju projektach, które przybliżały kulturę żydowską i jej zwyczaje, organizowanych między innymi przez Dzielnicę Wzajemnego Szacunku Czterech Wyznań, czy w wydarzeniach odbywających się podczas Festiwalu Kultury Żydowskiej SIMCHA. Jak się okazało, wiedzę na temat żydowskich zwyczajów pogrzebowych czy kultury żydowskiej w ogóle czerpano jednak głównie z kina, telewizji i internetu, rzadziej wskazywano zaś na książki czy edukację szkolną. Wspominano głównie o serialach kryminalnych i filmach dokumentalnych, wymieniając na przykład cykl Kadry Wrocławia: Festung Breslau - zagłada miasta oraz projekcję sztuki teatralnej Anioły Nowego Jorku, prezentowane w kinie Nowe Horyzonty (W9, W16).

Wrocławskie cmentarze żydowskie jawią się tym młodym mieszkańcom miasta, którzy je odwiedzili, jako tajemnicze, niedostępne, schowane przed wzrokiem osób postronnych, położone nieco na uboczu, choć znajdują się dziś niemal w centrum miasta i stały się częścią "lokalnej przestrzeni” i „lokalnej historii” (Mroczkowska 2016: 127). Zwiedzający postrzegali je przede wszystkim przez pryzmat wrażeń estetycznych, podkreślając piękno macew i grobowców, stanowiących znakomity przykład małej architektury, a także piękno samej przestrzeni nekropolii, z wydzielonymi, szerokimi alejkami, przenikającej się ze światem przyrody. Postrzegali je także przez pryzmat historii - jako przestrzeń historyczną, wypełnioną cennymi zabytkami kultury materialnej, wartościowe dziedzictwo zarówno żydowskie, jak i o znaczeniu lokalnym, ale jednocześnie jako miejsca, w których od dawna nie odbywają się pochówki, w których zawieszono rytuały, oraz przez pryzmat pamięci - jako miejsce stanowiące pamiątkę po obecności Żydów w dawnym Wrocławiu. Stary cmentarz żydowski był jednak traktowany nie tylko jako miejsce pamięci i upamiętnienia dawnych Żydów, ale także w dużym stopniu jako swoista przestrzeń muzealna, gromadząca dzieła sztuki, piękne grobowce wykonane z cennych materiałów i nagrobki o walorach artystycznych. Podobne spostrzeżenie na temat nowych funkcji przedwojennych cmentarzy na terenach postimigracyjnych poczyniła Zawiła (2019a: 136), pisząc, że: „Formy cmentarne spełniają tu funkcje eksponatów muzealnych, a sam cmentarz staje się galerią, w której można podziwiać kunszt dawnych mistrzów sztuki sepulkralnej”. Niektóre grobowce kojarzyły się rozmówcom także z pomnikami wystawionymi ku czci jakiejś znanej postaci: „To tam wygląda bardziej jak pomniki komuś znanemu wystawione niż jak nagrobki u nas” (W7), „U nas nagrobki to są takie małe, tam to bardziej przypomina takie ogromne pomniki, żeby kogoś upamiętnić, jest dużo kolumn, kopuł" (W11).

W żadnej wypowiedzi nie pojawiły się bezpośrednie skojarzenia cmentarzy żydowskich z sacrum, z miejscami postrzeganymi jako święte, z miejscami nieczystymi z powodów rytualnych lub chronionymi, za jakie miejsca pochówków uważa się zarówno w kręgu kultury żydowskiej, jak i chrześcijańskiej. W kilku wypowiedziach podkreślono jednak wyraźne wyodrębnienie cmentarzy poprzez 
ich ogrodzenie wysokim murem, za którym według rozmówców, rozpościera się inny, tajemniczy świat, postrzegany przez nich - jak wynika z narracji - właśnie jako rodzaj niedostępnego sacrum, oddzielonego od świata profanum ${ }^{10}$. Jedni zwracają na niego uwagę, zaciekawieni tą egzotyką wkraczają w jego przestrzeń, odkrywając miejsce, które zaskakuje ich swoim artystycznym wyrazem i specyficzną atmosferą; inni prawie go nie dostrzegają, mieszkając obok czy przechodząc codziennie, nigdy nie interesowali się tym, co znajduje się za murem cmentarza.

Taki sposób postrzegania cmentarzy, kojarzenie ich głównie z funkcją historyczną, estetyczną, turystyczną czy rekreacyjną świadczy o zmianie ich znaczenia jako przestrzennych nośników pamięci. Jak pisze Zawiła (2019b: 73): „Inne znaczenie miały one jako nośniki pamięci zbiorowej dla członków wspólnoty, która je założyła i która z nich korzystała jako miejsc pochówku swoich członków, inne dla ludności zasiedlającej nowe dla siebie tereny po wojnie, a jeszcze inne mogą mieć współcześnie dla potomków obu tych grup".

\section{Pamięć zbiorowa i zapominanie w kontekście Wrocławia}

Powojenne migracje i całkowita wymiana ludności na ziemiach zachodnich sprawiły, że na rozpatrywanym terenie nastąpiło zerwanie ciągłości przekazu kulturowego. Dawni mieszkańcy zostali przymusowo wysiedleni, a nowi, których również zmuszono do porzucenia swoich miejsc osiedlenia, przenieśli się w zupełnie inne, obce warunki i nieznaną sobie przestrzeń. Pamięć, jaką dysponowali przybyli, nie obejmowała nowych miejsc, zamieszkałych tu dawniej ludzi i ich kultury. Dotyczyła zupełnie innych wspólnot i innych przestrzeni. Ciągłość kulturowa została przerwana.

Według Barbary Pabjan, która prowadziła badania nad pamięcią zbiorową mieszkańców Wrocławia w latach 2012-2014, fakt, że mamy tu do czynienia z pamięcią zbiorowości wykorzenionej, bez ciągłości miejsca, i z miastem, które jest nośnikiem pamięci o innych, obcych kulturach, nadal ma duże znaczenie dla kwestii postrzegania miasta i jego przeszłości przez mieszkańców. Świadczą o tym między innymi negatywne reakcje na próby upamiętniania jego dawnych, niemieckich mieszkańców, obywateli zasłużonych dla jego dziejów, czy propozycje odbudowania dawnych zabytków (Pabjan 2015: 30). Pabjan zauważyła również, że „wrocławianie nie interesują się historią, znaczenie historii jest raczej deklarowane" i symboliczne, rzadko też uczestniczą w tzw. praktykach upamiętniających, co pozwoliło jej postawić tezę o „pustej” pamięci mieszkańców miasta i braku „jakiegoś wyraźnego, szczególnego rysu lokalnego" treści pamięci historycznej wroc-

10 Na ogradzanie i wyłączanie w ten sposób z całości przestrzeni cmentarzy jako miejsc uświęconych zwraca uwagę między innymi S. Sikora (1986: 58-59), odwołując się do analiz M. Eliadego (1966). 
ławian, którzy mają raczej pamiętać wydarzenia o charakterze ogólnopolskim niż lokalnym (Pabjan 2015: 23, 24). Mieszkańcy miasta, nieidentyfikujący się z jego „obcą”, niemiecką przeszłością i nieznający jej, nie są zwykle zainteresowani także żydowską częścią tej przeszłości, przez niektórych, jak się wydaje, również utożsamianą z „niemieckością”. O identyfikowaniu przez część respondentów cmentarzy żydowskich i budynków należących do Żydów z niemiecką przeszłością miasta świadczą ich wypowiedzi: „Wrocław wcześniej był niemieckim miastem i ci Żydzi tu pochowani (na starym cmentarzu żydowskim - EBO) to są Żydzi niemieccy (...) na przykład na tej naszej kamienicy, w której pracuję, są jakieś super rzeźby, ale one też są niemieckie” (W7), „W sumie Wrocław był niemieckim miastem, więc to są cmentarze Żydów niemieckich” (W5), „Przedwojenny Wrocław to był niemiecki Breslau i ci Żydzi z Breslau posiadali znane budynki, na przykład Feniks był braci Barasch” (W9), „Kiedy Wrocław jeszcze był niemieckim miastem, dużą część mieszkańców stanowili Żydzi i nawet zostało trochę śladów po tych niemieckich Żydach, jak cmentarze" (W38). Pozostawione cmentarze żydowskie mogą być więc traktowane jako przestrzenne nośniki „obcej”, „nie naszej” pamięci. Jak pisze Zawiła, zerwanie historycznej ciągłości osadnictwa w wyniku migracji, brak międzypokoleniowej, kulturowej i społecznej ciągłości między tymi, którzy je wytworzyli, i tymi, którzy je zastali w „nowym, postimigracyjnym kontekście", sprzyja zapominaniu. Miejsca pamięci nie o własnej wspólnocie, lecz o innych stają się "miejscami pamięci niewygodnej”, a obce dziedzictwo niechciane lub odrzucone (Zawiła 2019b: 72, 75-76; zob. też Stachowiak 2015). Według Golki z kolei to, co zapomniane, lokuje się poza społeczną świadomością członków grupy (Golka 2009: 145). Wskazuje on na kilka przyczyn zapominania, które mogą mieć znaczenie także w kontekście analizowanego problemu. Są to: upływ czasu, powojenne przemilczanie (w tym wypadku można mówić wręcz o wymazywaniu niemieckich śladów, w tym również tych związanych z Żydami) oraz zmiany pokoleniowe. Golka zauważa: „Zwraca się niekiedy uwagę na pewien cynizm, a przynajmniej ironię wobec pamięci społecznej w tzw. pokoleniu $\mathrm{X}$ z końca XX wieku (...). Wydaje się to jednak bardziej uniwersalnym procesem w społeczeństwach współczesnych, w których młode generacje bagatelizują czy wręcz odrzucają znaczną część przeszłości, a przede wszystkim wiedzy o niej” (Golka 2009: 147-149).

Na proces zapominania Żydów i kultury żydowskiej w kolejnych, młodszych pokoleniach, zwrócił również uwagę Jacek Nowak, analizując mechanizmy przepracowania pamięci zbiorowej o kulturze żydowskiej w społecznościach lokalnych Polski południowo-wschodniej. Zauważył, że „O ile pokolenie urodzone zaraz po wojnie (dzisiejsi 70-latkowie) ma jeszcze szczątkową, ale też nieuporządkowaną pamięć o Żydach odziedziczoną od świadków zdarzeń sprzed wojny, o tyle ich dzieci (50-latkowie i młodsi) mogą się dzielić z nami jedynie strzępami wspomnień swoich dziadków" (Nowak 2017: 67-68). Wskazuje również, że jedną z przyczyn zapominania Żydów, niewłączania ich do kanonu biograficznych 
wspomnień starszych pokoleń, była ich obcość, brak pogłębionych relacji. Ponieważ młodsze pokolenia nie omówiły z dziadkami przeszłości, która uwzględnia Żydów, współcześnie mamy do czynienia z brakiem przetworzonej pamięci o nich wśród następnych pokoleń, a także, $\mathrm{w}$ rezultacie, $\mathrm{z}$ brakiem naturalnej ciekawości i potrzeby poszukiwania wiedzy o Żydach (Nowak 2017: 70-71). Wydaje się, że wszystkie te spostrzeżenia możemy odnieść do sytuacji zapominania Żydów i miejsc z nimi związanych w kontekście wrocławskim. Przy tym wspomniana przez Nowaka obcość tutaj nabiera podwójnego znaczenia. Żydzi są obcy nie tylko kulturowo i wyznaniowo, są obcy, bo postrzegani jako część niemieckiej przeszłości miasta, a ich cmentarze reprezentują obcą, niechcianą pamięć.

\section{Zakończenie}

Podsumowując, raz jeszcze warto odnieść się do słów Golki, że to, co zapomniane, lokuje się poza społeczną świadomością członków grupy, jest więc nieuświadamiane, a zatem i nieznane. Zapominanie Żydów, nieuwzględnianie ich we wspomnieniach przekazywanych międzygeneracyjnie, $w$ rodzinie, jest jedną z przyczyn braku zainteresowania wśród młodych ludzi Żydami w ogóle, a także pozostałymi po nich śladami materialnymi, takimi jak cmentarze. Istotną rolę odgrywa także wspomniane wcześniej bagatelizowanie czy niedocenianie przeszłości i wiedzy o niej. W przypadku Wrocławia - jak wykazały badania Pabjan - okazało się, że jest to właściwe nie tylko dla młodych osób, ale także stanowi charakterystyczny rys pamięci zbiorowej mieszkańców miasta i wynika w dużej mierze z tego, że jego niemiecka przeszłość nadal może być nieoswojona przez dużą część mieszkańców. Z kolei jego żydowska przeszłość wielu osobom jest nieznana. Z badań CBOS przeprowadzonych w 2015 roku wynika, że mieszkańcy miast południowozachodniej Polski rzadziej są świadomi tego, że przed wojną żyli w nich Żydzi. Taką wiedzę miało tylko 35\% mieszkańców i był to najniższy odsetek w Polsce (Roguska 2015: 13). W tym przypadku problemem, na który warto zwrócić uwagę, a który akcentowali także sami respondenci w kontekście wiedzy na temat Żydów we Wrocławiu i związanych z nimi miejsc, jest z pewnością również niewystarczająca edukacja w kontekście lokalnym. Część rozmówców wprost przyznawała, że po zakończeniu edukacji szkolnej i odwiedzeniu Muzeum Historii Żydów Polskich POLIN więcej wie na temat historii Żydów w Warszawie niż o Żydach we własnym mieście i ich cmentarzach. Potwierdzają to także przeprowadzone badania, z których wynika, że tylko osiem osób (wśród których 25\% pochodzi z grupy UW i 75\% z grupy SW), czyli 14\% z całej grupy badanych, dysponowało bardziej szczegółową wiedzą na temat wrocławskich cmentarzy żydowskich i zwyczajów tam praktykowanych. Wiedza ta wynikała z zainteresowania kulturą żydowską bądź cmentarzami w ogóle, uczestniczenia w różnych wydarzeniach 
kulturalnych i edukacyjnych organizowanych przez gminę żydowską, a także $\mathrm{z}$ rodzaju wykształcenia części rozmówców. Wśród respondentów zdecydowanie dominowały jednak osoby, których wiedza była bardzo pobieżna, powierzchowna (często operowano hasłami, za którymi nie kryła się żadna treść) oraz oparta na domysłach, stereotypach i wyobrażeniach, których źródłem były najczęściej seriale telewizyjne i internet. Była to grupa 34 badanych, czyli $61 \%$ ogółu, (w tym $41 \%$ z grupy UW, 59\% z grupy SW); 14 badanych, czyli $25 \%$ ogółu, nie wiedziało nic o cmentarzach żydowskich i praktykowanych na nich zwyczajach, nie słyszało również o ich istnieniu we Wrocławiu (57\% z grupy UW i 43\% z grupy SW). Warto jeszcze zwrócić uwagę na dane porównujące obie grupy mieszkańców. Tylko 8\% grupy UW i 19\% grupy SW dysponowało bardziej szczegółową wiedzą na temat wrocławskich cmentarzy żydowskich i praktykowanych zwyczajów; 59\% osób z grupy UW i $62 \%$ z grupy SW miało bardzo zdawkową, hasłową wiedzę, opartą na wyobrażeniach i stereotypach; 33\% grupy UW i 19\% grupy SW zupełnie nic nie wiedziało o cmentarzach żydowskich i praktykowanych zwyczajach, nie miało również świadomości istnienia takich cmentarzy we Wrocławiu. Były to dla nich miejsca abstrakcyjne, tytułowe miejsca nieznane czy też znane tylko „ze słyszenia”, często traktowane jako punkty orientacyjne na mapie miasta, ułatwiające lokalizację w terenie; obce światy, choć często bliskie w sensie przestrzennym. Również w wypowiedziach rozmówców można było odnieść wrażenie wspomnianej wcześniej podwójnej obcości cmentarzy żydowskich. Po pierwsze, postrzeganych jako cmentarze obce kulturowo i wyznaniowo, po drugie, traktowanych jako spuścizna materialna po Żydach niemieckich, a więc tym bardziej obca, bo niebędąca częścią własnej przeszłości, historii oraz tradycji i dlatego niebudząca większego zainteresowania, nieatrakcyjna, nieznacząca i stanowiąca w pewnym sensie niechciane dziedzictwo. Podejmowane w sferze publicznej i instytucjonalnej działania mające przypomnieć oraz upamiętnić Żydów i ich dziedzictwo, ale także zwrócić uwagę na dzisiejszą społeczność żydowską w mieście - wobec braku odpowiedniej edukacji i międzypokoleniowego przekazu w rodzinie - nie mają wystarczającego przełożenia na pamięć o Żydach wrocławskich, a tym samym na wiedzę i wyobrażenia na temat związanych z nimi miejsc, takich jak cmentarze. Odwołując się do słów Sławomira Kapralskiego, który pisał o Żydach i zagładzie w polskich kulturach pamięci, upamiętnienie w płaszczyźnie pamięci kulturowej nie oznacza, że Żydzi, a w tym przypadku ich pozostawione dziedzictwo, staną się „integralną częścią pamięci komunikacyjnej w skali masowej (...) oni są upamiętniani, a nie pamiętani" (Kapralski 2016: 354). 


\section{Bibliografia}

Bałaban M.

1929 Zabytki historyczne Żydów w Polsce, Warszawa.

Banasiewicz-Ossowska E.

2005 Śmierć w tradycji i wierzeniach Żydów polskich, w: Problemy współczesnej tanatologii. Medycyna - antropologia kultury - humanistyka, t. 9, red. J. Kolbuszewski, Wrocław, s. 335-340.

2007 Między dwoma światami. Żydzi w polskiej kulturze ludowej, „Prace i Materiały Etnograficzne", t. 35, Wrocław.

2014 Tradycja i współczesność w obrzędowości pogrzebowej Żydów wrocławskich, w: Praktykowanie tradycji $w$ społeczeństwach posttradycyjnych, red. J. Hajduk-Nijakowska, Opole, s. 189-207.

2020 Żydzi wrocławscy w świadomości młodych mieszkańców Wrocławia - wiedza i stereotypy, „Edukacja Międzykulturowa”, nr 1 (12), s. 169-181.

Bednarek M.

2020 Sytuacja prawna cmentarzy żydowskich w Polsce w latach 1944-2019, Kraków.

Biegeleisen H.,

1929 Lecznictwo ludu polskiego, Kraków.

1930 Śmierć w obrzędach, zwyczajach i wierzeniach ludu polskiego, Warszawa.

Bielawski K.

2020 Zagłada cmentarzy żydowskich, Warszawa.

Borzymińska Z., Żebrowski R.

2003 Polski słownik judaistyczny. Dzieje. Kultura. Religia. Ludzie, t. 1, Warszawa.

Brzezińska A., Aplet K., Ziółkowska B.

2008 Psychologia rozwoju człowieka, w: Psychologia. Podręcznik akademicki, t. 2, red. J. Strelau, D. Doliński, Gdańsk, s. 95-298.

Carmel P., Gruber R .R., Szemző H., Tönkő A., Vonnák D.,

2020 Jewish Cemeteries and Sustainable Protection the ESJF handbook of sustainable heritage tourism, Frankfurt, https://issuu.com/esjf/docs/jewish_cemeteries_and_sustainable_protection (dostęp: 13.01.2021).

Eliade M.

1966 Traktat o historii religii, przeł. J. Wierusz-Kowalski, Warszawa.

Erikson E.,

1997 Dziedzictwo i społeczeństwo, przeł. P. Hejmej, Poznań.

Fabiszak M., Brzezińska A.W.

2018 Cmentarz - park - podwórko. Poznańskie przestrzenie pamięci, Warszawa.

Gadowska I.

2017a Wielkomiejskie cmentarze żydowskie. Metamorfoza przestrzeni jako czynnik desakralizacji, w: Adlojada. Kultura i profanacje, red. J. Brejdak, D. Kacprzak, J. Madejski i in., Szczecin, s. 111-121.

Gadowska I. (red.)

2017 bielkomiejskie cmentarze żydowskie w Europie Środkowo-Wschodniej, Łódź.

Gliwka G.

2019 Pamięć zbiorowa - jej funkcje i mechanizmy przekazu w kontekście badań Barbary Szackiej i Andrzeja Szpocińskiego, „Rozprawy Społeczne”, t. 13, nr 3, s. 13-27. http:// 
yadda.icm.edu.pl/yadda/element/bwmeta1.element.ekon-element-000171582326 (dostęp: 18.01.2021).

Gogol J., Henke L., Hoffman S., Kazejak I., Sęczek A.

2005 Wielka tradycja bez kontynuacji. Gmina Żydowska we Wrocławiu po roku 1945, https://homepage.univie.ac.at/philipp.ther/breslau/html/wielka.html (dostęp: 15.01.2021).

Goldberg-Mulkiewicz O.

1986 Obrzędy żałobne i pogrzebowe Żydów polskich, „Polska Sztuka Ludowa”, r. 40, nr 1-2, s. 103-107.

2000 Cmentarze $\dot{z} y d o w s k i e, \mathrm{w}$ : „Lebn wil ich” - „ja chcę $\dot{z} y$ ć. To co pozostało: cmentarze $\dot{z} y d o w s k i e w$ Polsce, oprac. i red. P. Blachetta-Madajczyk, Białystok.

Goliński M., Ziątkowski L.

1989 Średniowieczne cmentarze żydowskie we Wrocławiu, „Śląski Kwartalnik Historyczny Sobótka, r. 44, s. 35-43.

Golka M.

2009 Pamięć społeczna i jej implanty, Warszawa.

Gruber R.E.

2004 Odrodzenie kultury żydowskiej w Europie, przeł. A. Nowakowska, Sejny.

Grzywa J.

2010 Zapomniane „sacrum” - cmentarze ludności niemieckiej i żydowskiej jako problem społeczno-kulturowy wspótczesnego miasta, „Studia Etnologiczne i Antropologiczne”, nr 10, s. 386-404.

Hońdo L.

2002 Przestrzeń żydowskiego cmentarza, w: Śmierć, przestrzeń, czas, tożsamość w Europie Środkowej około 1900. Materiały międzynarodowej konferencji zorganizowanej w dniach 8-10 grudnia 1996, red. K. Grodziska, J. Purchla, Kraków, s. 195-214.

Jagielski J.,

1995 Obecny stan cmentarzy żydowskich w Polsce, w: Cmentarze żydowskie. Studia $z$ dziejów kultury żydowskiej w Polsce, t. 2, red. J. Woronczak, Wrocław s. 229-232.

Kapralski S.

2016 Żydzi i zagłada w polskich kulturach pamięci: między antagonizmem i agonem, „Teksty Drugie”, nr 6, s. 346-357, https://rcin.org.pl/Content/63030/WA248_82864_P-I-2524_kapralski-zydzi_o.pdf (dostęp: 18.01.2021).

Karpińska G.E.

2017 Cmentarz. Antropologiczna lektura przestrzeni i pamięci na przykładzie wiejskiego cmentarza w Złotym Potoku, „Literatura Ludowa”, nr 1, s. 21-31.

Kichler J.

2015 Cmentarz Cosel we Wrocławiu, w: Jerzy Kichler. Odrodzenie życia żydowskiego we Wrocławiu. Człowiek dialogu, red. J. Lisek, M. Szajda, Wrocław, s. 40-58.

Kichler J., Włodarczyk T.

2016 Przewodnik po żydowskim Wrocławiu, Wrocław.

Klein R.

2015 Witnesses of emancipation. Selected metropolitan Jewish cemeteries of Central and Eastern Europe, Berlin.

2019 Metropolitan Jewish Cemeteries of the $19^{\text {th }}$ and $20^{\text {th }}$ Centuries in Central and Eastern Europe. A Comparative Study, Petersberg. 
Klimowicz T., Sygowski P., Tarajko M., Trzciński A.

2018 Ogrodnicy pamięci. Cmentarze żydowskie. Podręcznik dobrych praktyk w ochronie dziedzictwa lokalnego, Lublin.

Kolbuszewski J.

1995 Semiotyczny pejzaż cmentarza, w: Cmentarze żydowskie. Studia z dziejów kultury zydowskiej w Polsce, t. 2, red. J. Woronczak, Wrocław, s. 27-37.

1996 Cmentarze, Wrocław.

Krajewska M.

1989 Cmentarze żydowskie w Polsce: nagrobki i epitafia, „Polska Sztuka Ludowa”, r. 43, z. 1-2, s. 27-44.

Łagiewski M.

1991 Macewy mówią, Wrocław-Warszawa-Kraków.

1997 Wrocławscy Żydzi 1850-1944, Wrocław.

2004 Stary cmentarz żydowski we Wrocławiu, Wrocław.

Majewska A.

2016a Cmentarz a nekropolia - „tradycja” a asymilacja? Cmentarze żydowskie w przestrzeni miast województwa śląskiego, w: Wielkomiejskie cmentarze żydowskie w Europie Środkowo-Wschodniej, red. I. Gadowska, Łódź, s. 37-62.

2016b Dziedzictwo opuszczone na przykładzie cmentarzy żydowskich województwa śląskiego. Uwarunkowania i zagrożenia naturalne, w: Wspólne dziedzictwo kulturowe. Dialog kultury z natura, red. M. Winograd, Białystok, s. 250-270.

Mroczkowska A.

2016 Ochrona cmentarza żydowskiego $w$ Sobieniach-Jeziory w kontekście działań instytucjonalnych i praktyk społecznych, „Rocznik Antropologii Historii”, r. VI (9), s. 123-146.

Nowak J.

2011 Społeczne reguły pamiętania. Antropologia pamięci zbiorowej, Kraków.

2017 Pamięć kulturowa i zapominanie o Żydach, „SENSUS HISTORIAE”, t. 27, nr 2, s. $63-76$.

Okólska H., Burak M.

2007 Cmentarze dawnego Wrocławia, Wrocław.

Pabjan B.

2015 Pamięć zbiorowa mieszkańców miasta. Studium o badaniach pamięci zbiorowej, „Acta Universitatis Lodziensis. Folia Sociologica”, nr 54, s. 17-37.

Pabjan B., Czajkowski P.

2013 Pamięć zbiorowa mieszkańców Wrocławia a stosunek do niemieckiego dziedzictwa miasta, w: Współczesna teoria i praktyka badań społecznych i humanistycznych, red. J. Juchnowski, R. Wiszniewski, s. 739-761, https://www.researchgate.net/publication/260138716_Pamiec_zbiorowa_mieszkancow_Wroclawia_a_stosunek_do_niemieckiego_dziedzictwa_miasta (dostęp: 19.01.2021).

Reisenthel A.

2015 Orientalismus als Mittel zur Identitatsfindung. Sepulkralarchitektur auf dem Jüdischen Friedhof Breslau, Lohestraße, Berlin.

Roguska B.

2015 Postrzeganie Żydów i stosunków polsko-żydowskich. CBOS. Komunikat z badań, nr 112, https://cbos.pl/SPISKOM.POL/2015/K_112_15.PDF (dostęp: 29.02.2020). 


\section{Rozmus D.}

2015 Przestrzenne zastosowanie obyczajowego prawa religijnego na przykładzie cmentarza żydowskiego, „Roczniki Administracji i Prawa”, nr XV (1), s. 99-111.

Sikora S.

1986 Cmentarz. Antropologia pamięci, „Polska Sztuka Ludowa - Konteksty”, nr 1-2, s. $57-68$.

Skrok Z.

1991 Kłódki symboliczne. Przyczynek do zwyczajów pogrzebowych Żydów polskich, „Polska Sztuka Ludowa”, r. 45, nr 2, s. 18-20.

Stachowiak A.

2015 Niemieckie cmentarze na Ziemiach Zachodnich jako miejsca niepamięci, „Zeszyty Naukowe Uniwersytetu Jagiellońskiego. Prace Etnograficzne”, t. 43, z. 2, s. 123-140.

Stawiarski B.

2010 Cmentarze Żydów aszkenazyjskich w średniowieczu. Przykład Wrocławia, „Wratislavia Antiqua”, t. 12, s. 61-290.

Steuer-Jurek A.

2019 Kultywowanie miejsc pamięci na przykładach cmentarzy w Głogówku, „Przestrzeń/Urbanistyka/Architektura”, nr 1, s. 133-144.

Szacka B.

2006 Czas przeszły, pamięć, mit, Warszawa.

Tanaś S.

2008a Miejsce cmentarzy w turystyce kulturowej - wokół problemu badawczego, „Turystyka Kulturowa”, nr 2, s. 4-16, http://www.turystykakulturowa.org/pdf/2008_12_01. pdf (dostęp: 20.11.2020).

2008b Przestrzeń turystyczna cmentarzy. Wstęp do tanatoturystyki, Łódź.

Trzciński A.

1997 Symbole i obrazy. Treści symboliczne przedstawień na nagrobkach żydowskich $w$ Polsce, Lublin.

2010 Cmentarze żydowskie w XIX i XX wieku (do Holokaustu) w Europie Środkowo-Wschodniej jako tekst kultury, w: Sztuka cmentarzy w XIX i XX wieku, red. A.S. Czyż, B. Gutowski, Warszawa, s. 265-281.

Walerjański D.

1998 Cmentarze żydowskie w województwie katowickim: historia, stan zachowania, problemy ochrony, „Ochrona Zabytków”, t. 51/3, s. 246-257.

Wilczura A.

2010 Śmierć i życie pozagrobowe $w \dot{z} y$ dowskich wierzeniach ludowych, „Studia Bliskowschodnie", nr 4, s. 34-41, https://depot.ceon.pl/bitstream/handle/123456789/4266/ Wilczura - Śmierć i życie pozagrobowe.pdf?sequence=1\&isAllowed=y (dostęp: 10.11. 2020).

Wodziński M.

1992 Epitafia hebrajskie z cmentarza żydowskiego we Wrocławiu przy ul. Lotniczej, „Annales Silesiae”, nr 22, s. 91-103.

1994 Średniowieczny cmentarz żydowski we Wrocławiu, „Śląski Kwartalnik Historyczny Sobótka", r. 49, z. 3-4, s. 341-344.

Woronczak J.P.

1991 Specyfika kulturowa cmentarzy żydowskich, Katowice.

Woronczak J.P. (red.)

1995 Cmentarze żydowskie. Studia z dziejów kultury żydowskiej w Polsce, t. 2, Wrocław. 
Zawiła M.

2019a Dziedziczynienie przedwojennych cmentarzy na terenach postimigracyjnych Polski, Kraków.

2019b Przedwojenne cmentarze na terenach postimigracyjnych Polski. Między niepamięcia a dziedzictwem, w: Śmierć. Figury obecności - figury zapomnienia, red. A. Kaczmarek, M. Kamińska, „Studia Kulturoznawcze”, nr 1, s. 71-88. 